\title{
MENGKRITISI RANCANGAN UNDANG-UNDANG PENGADAAN TANAH UNTUK KEPENTINGAN PEMBANGUNAN, SUATU CATATAN KRITIS ${ }^{1}$
}

\author{
Imam Koeswahyono ${ }^{2}$
}

\begin{abstract}
Acquisition of land as a legal institution to obtain land for the government in carrying out development activities for the public interest in the legal history of Indonesia is always full of irregularities. land acquisition continues the debate narrowed down only about the meaning of public interest, consensus, and real compensation sharpened on essential issues such as inequality in land control and ownership structure, so that the poor benefited and suffered the injustice of this law shall enjoy the protection of the state (government). This study is to analyze thoroughly how the substantial weaknesses in the bill of material acquisition of land for public interest isn't properly handled, rather than just the interests of profit instead hiding behind the public interest. Attitudes needed criticism and rejection of the presence of the bill that would create injustice and resistance. Inconsistency plan of land acquisition laws are indeed a step back setting back setting for the acquisition of land in accordance with the Minister of State in New Order era. In addition, predictable legal implications of the enactment of the bill will further resolve the agrarian or land cases.
\end{abstract}

Keywords: land acquisition, development, public interest

\begin{abstract}
Abstrak
Pengadaan tanah sebagai suatu lembaga hukum untuk mendapatkan tanah bagi aktifitas pemerintah dalam menjalankan pembangunan bagi kepentingan umum

1 Tulisan khusus untuk "Majalah Hukum Arena Hukum" Fakultas Hukum Universitas Brawijaya merupakan revisi menyeluruh dari makalah bahan diskusi rutin Pusat Pengembangan Hukum Agraria (PPHA) Fakultas Hukum Universitas Brawijaya, Kamis 12 Mei 2011. Tulisan ini merupakan pandangan pribadi penulis dan bukan merupakan pandangan dari Pusat Pengembangan Hukum Agraria (PPHA) Fakultas Hukum Universitas Brawijaya Unibraw.

${ }^{2}$ Sekretaris PPHA, Dosen Hukum Agraria 1987 - sekarang, mahasiswa S-3 Ilmu Hukum
\end{abstract}


dalam sejarah hukum Indonesia senantiasa penuh dengan penyimpangan. debat pengadaan tanah senantiasa dipersempit hanya berkisar pada makna kepentingan umum, musyawarah untuk mufakat serta ganti kerugian sesungguhnya dipertajam pada masalah esensial yakni ketimpangan struktur penguasaan dan pemilikan tanah, sehingga pihak yang kurang diuntungkan dan mengalami ketidakadilan inilah yang wajib mendapatkan perlindungan hukum dari negara (pemerintah). Kajian ini hendak mengupas tuntas bagaimana kelemahan substansial pada materi rancangan undang-undang pengadaan tanah untuk kepentingan umum belum tertangani, alihalih justru kepentingan profit justru bersembunyi di balik kepentingan umum. Diperlukan adanya sikap kritik dan penolakan atas kehadiran rancangan undangundang yang bakal menciptakan ketidakadilan dan resistensi ini.Inkonsistensi rancangan undang-undang pengadaan tanah sesungguhnya merupakan langkah mundur pengaturan karena kembali pada pengaturan pengambilalihan tanah menurut Peraturan Menteri dalam Negeri pada era Orde Baru. Disamping itu, diprediksi implikasi hukum dari pengundangan rancangan undang-undang akan semakin menumbuhkembangkan kasus agraria.

Kata Kunci: pengadaan tanah, pembangunan, kepentingan umum

\section{Pengantar}

Salah satu produk hukum yang hendak diundangkan pada era Kabinet Indonesia Bersatu Ke II adalah Rancangan Undang-undang Pengadaan Tanah Untuk Pembangunan yang selanjutnya disingkat dengan RUU PTUP, menimbulkan pendapat pro dan kontra di masyarakat. Sudah barang tentu, berbagai pendapat pro dan kontra yang dikeluarkan oleh berbagai elemen masyarakat, masing-masing memiliki dasar alasan, argumentasi. Salah satu di antara pendapat yang menolak RUU PTUP adalah Idham Arsyad yang intinya menyatakan pembahasan RUU PTUP ini sebaiknya ditunda sampai penataan struktur agraria dilakukan dengan mendorong pelaksanaan reforma agraria. ${ }^{3}$ Sebelumnya harian Kompas juga mewartakan bahwa RUU PTUP merupakan ancaman hak atas tanah karena rawan hal. 6 .

\footnotetext{
${ }^{3}$ Periksa Idham Arsyad, Sesat Pikir RUU Pengadaan Tanah, KOMPAS, Jum'at 18 Maret 2011,
} 
diselewengkan untuk kepentingan bisnis yang justru meminggirkan akses publik terhadap hasil pembangunan, sehingga dinilai tidak berpihak kepada rakyat. ${ }^{4}$

Dalam tulisan kali ini penulis menelaah materi RUU PTUP ini dari perspektif disiplin hukum lebih khusus telaah dari sisi struktur atau format peraturan perundangan menurut UU No.10 tahun 2004 dan keterkaitan antara hukum dan keadilan sosial (social justice).

Mengapa nilai keadilan sosial menjadi alasan sebagai pengarusutamaan karena sejarah bangsa membuktikan terjadinya ketimpangan struktur sosial yang tidak adil (unjustice). Kedua keadilan sosial adalah:

Keadilan yang pelaksanaannya tidak lagi tergantung pada kehendak pribadi, pada kebaikan individu yang bersikap adil, tetapi sudah brsifat struktural. Artinya, pelaksanaan keadilan sosial tersebut sangat tergantung kepada penciptaan struktur sosial yang adil. Mengusahakan keadilan sosial berarti harus dilakukan melalui perjuangan memperbaiki struktur-struktur sosial yang tidak adil tersebut. ${ }^{5}$

Dengan demikian setidaknya terdapat permasalahan atau isu hukum penting yang diketengahkan berkenaan dengan kehadiran rancangan undang-undang tentang pengadaan tanah untuk kepentingan pembangunan sebagaimana ditetapkan sebagai topik tulisan ini mempersoalkan mengenai sinkronisasi dan harmonisasi rancangan undang-undang pengadaan tanah dengan peraturan perundangan yang terkait yakni Undang-undang No.5 Tahun 1960, Undang-undang No.20 Tahun 1961 berdasarkan kajian normatif menurut Undang-undang No.10 Tahun 2004 tentang Pembentukan peraturan perundang-undangan.

\section{Permasalahan}

Bagaimana sinkronisasi dan harmonisasi rancangan undang-undang tentang pengadaan tanah dengan Undang-undang Dasar Negara Republik Indonesia Tahun 1945 jo Undang-undang No.5 Tahun 1960 dan konsekuensi hukum atasnya?

${ }^{4}$ Kompas, Ancaman Hak Atas Tanah, Jum'at 11 Maret 2011, hal. 4.

${ }^{5}$ Ulli Parulian Sihombing dkk (Perumus), "Mengajarkan Hukum Yang Berkeadilan, Cetak Biru Pembaruan Pendidikan Hukum Berbasis Keadilan Sosial", Cetakan Pertama, (Jakarta: ILRC \& OSI, 2009), hal. $19-20$. 


\section{Pembahasan: Struktur, Filosofi, Nomenklatur, Prinsip/Azas}

\section{Struktur}

Perlu diketahui bahwa sebelum disusunnya RUU PTUP, maka wujud pengaturan aktifitas PTUP secara berturut-turut adalah Peraturan Menteri Dalam Negeri No.15 Thn 1975, Keputusan Presiden No.No.55 Thn 1993, Peraturan Presiden No.36 Thn 2005 serta terakhir Peraturan Presiden No.65 Thn 2006 sebagai realisasi dari amanat: pertama Pasal 6, 27, 34,40 UUPA.Kedua sebagai amanat dari UU No.39 Thn 1999 tentang HAM yang mengamanatkan bahwa sebagai konsekuensi sumber daya tanah merupakan salah satu bagian dari HAM, maka kegiatan yang bertautan dengannya (Sumber Daya tanah) harus diatur dengan undang-undang.

Terminologi pengadaan tanah sesungguhnya tidak dikenal dalam Undangundang No.5 Tahun 1960, karena berdasarkan Pasal 27, Pasal 34 serta 40 mengenai berakhirnya hak milik atas tanah hanya dikenal perbuatan hukum pelepasan hak atas tanah dan penyerahan hak atas tanah.

Disamping itu berdasar Pasal 18 dikenal pula perbuatan hukum pencabutan hak atas tanah. Perbuatan pelepasan hak atas tanah dilakukan bilamana subyek hak atas tanah mendapatkan permintaan dari negara yang dilakukan oleh pemerintah/ pemerintah daerah yang menghendaki hak atas tanah untuk kegiatan pembangunan bagi kepentingan umum (public interests) berdasarkan ketentuan Pasal 6 bahwa semua hak atas tanah berfungsi sosial.

Sedangkan penyerahan hak atas tanah terjadi bilamana hak atas tanah selain hak milik diserahkan oleh subyek haknya kepada negara (pemerintah) sebelum jangka waktunya berakhir karena ketentuan Pasal 6 pula.

Implikasi hukum terkait dengan perbuatan hukum pelepasan hak atas tanah maupun pelepasan hak atas tanah sama yakni hapusnya hak atas tanah dari subyek hukum yang bersangkutan dan status hukum obyek tanahnya menjadi tanah yang dikuasai oleh negara sebagaimana diatur Pasal 2 jo Pasal 4 Undangundang No.5 tahun 1960. Disamping itu hal terpenting dari aktifitas atau perbuatan hukum pengadaan tanah untuk kepentingan pembangunan harus berpijak pada dasar konstitusional yakni Pasal 33 Ayat (3) Undang-undang Dasar 1945 dan Pasal 28 H Ayat (4) yang dinyatakan: 
Setiap orang berhak mempunyai hak milik pribadi dan hak milik tersebut tidak boleh diambil-alih secara sewenang-wenang oleh siapapun. ${ }^{6}$

\section{Filosofi}

Dasar filosofi yang harus menjadi basis RUU PTUP sebagaimana pula halnya dengan UUPA adalah Pancasila khususnya sila kedua, keempat serta kelima sebagaimana telah termaktub pada konsiderans RUU PTUP huruf a dan b. Seharusnya dengan pencantuman landasan filosofi tersebut harus mempertegas bahwa kegiatan pembangunan yang dimaksud sesungguhnya diabdikan untuk kepentingan siapa, dilakukan dengan cara yang bagaimana, serta bagaimana langkah mencapai cara dimaksud. Sila-sila Pancasila sebagaimana dinyatakan oleh Notonagoro (1984) merupakan pengisi dan pengarah serta menjiwai setiap norma-norma yang hendak dirumuskan ${ }^{7}$ Tulisan Notonagoro yang sama menyatakan bahwa:

Segala peraturan hukum yang ada dalam negara Indonesia mulai saat berdirinya merupakan suatu tertib hukum, ialah tertib hukum Indonesia. Dalam setiap tertib hukum diadakan pembagian susunan yang hierarkhis. Setiap peraturan perundangan yang diundangkan seharusnya merupakan penjabaran dari nilai-nilai yang terkandung dari sila-sila Pancasila yang seharusnya tiap kualifikasi setiap rumusan sila pertama dalam rangkaian kesatuan dengan sila-sila yang lainnya. ${ }^{8}$

${ }^{6}$ Imam Koeswahyono, Melacak Dasar Konstitusional Pengadaan Tanah Untuk Kepentingan Pembangunan Bagi Umum, dalam Jurnal Konstitusi PPK-FH Univ.Brawijaya Vol I No.1 Agustus 2008, hal. 34-36.

${ }^{7}$ Ibid., hal. 20-21 bandingkan pandangan Notonagoro yang menyatakan nilai Pancasila merupakan nilai universal dan tetap bilamana dibandingkan pandangan John Rawls, A Theory of Justice, Cambridge Harvard University Press, 2008: masyarakat dikatakan baik bilamana didasarkan dua prinsip: pertama fairness menjamin kebebasan maksimal semua anggota dan veil ignorance yang hanya membenarkan ketidaksamaan sosial dan ekonomi apabila ketidaksamaan itu dilihat dalam jangka panjang justru menguntungkan mereka yang kurang beruntung.

${ }^{8}$ Notonagoro, Beberapa Hal Mengenai Falsafah Pancasila, Pidato Dies Natalis Ke I Universitas Pantjasila, Cetakan Kedelapan, (Djakarta: Pantjuran Tudjuh, 1979), hal. 20 dan 33. 
Pada setiap tertib hukum esensi utamanya adalah sinkronisasi dan harmonisasi peraturan perundang-undangan dalam tata urutan berjenjang sebagaimana dirumuskan oleh Hans Kelsen dan Hans Nawiasky, sebagai sebuah susunan yang sistematik, logis, rasional dalam kerangka suatu tertib hukum.

\section{Nomenklatur}

Nomenklatur yang dimaksud adalah penamaan suatu produk hukum yang dalam ini adalah RUU harus jelas sekalipun acapkali didefinisikan pada Pasal 1 , namun agar tidak menimbulkan interpretasi yang beragam harus dituliskan secara jelas kegiatan pembangunan yang dimaksud meliputi aktifitas apa, bagaimana hal demikian dilaksanakan.Nampaknya RUU PTUP dapat dikatakan identik dengan Peraturan Menteri Dalam Negeri No.15 Tahun 1975 dan Peraturan Menteri Dalam Negeri No.1 Tahun 1976 yang mengedepankan pada pengkaburan makna kepentingan umum, sebagai kepentingan rakyat banyak. Sementara itu, RUU PTUP malah tidak memberikan definisi sama sekali apa yang dinamakan kepentingan umum, hal ini tentu akan menjadi pemicu munculnya kasus-kasus pengadaan tanah. Memasukkan kepentingan swasta sebagai kepentingan umum, merupakan kemunduran dari aspek hukum karena jelas akan menjadi cara melawan hukum pengambilan tanah oleh swasta yang berlindung di balik kepentingan umum. Padahal telah nyata bahwa kepentingan swasta tidak lain adalah kepentingan yang berorientasi pada keuntungan semata.

\section{Prinsip/Azas}

Asas hukum menurut Nieuwenhuis sebagaimana dikutip oleh Mertokusumo dimaknai sebagai:

Sebagian dari hidup kejiwaan kita. Dalam setiap asas hukum manusia melihat cita-cita yang hendak diraihnya, suatu cita-cita atau harapan, suatu ideal, memberikan dimensi etis kepada hukum pada umumnya merupakan suatu persangkaan. ${ }^{9}$

9 Sudikno Mertokusumo, "Penemuan Hukum, Sebuah Pengantar", Cetakan Pertama, (Yogyakarta: Liberty, 1996), hal. 8. 
Merujuk pada pandangan Maria SW Sumardjono sudah waktunya dalam kebijakan pengambilalihan tanah harus bertumpu pada prinsip demokrasi dan menjunjung tinggi HAM dengan memperhatikan hal-hal berikut:

(1). pengambilalihan tanah merupakan perbuatan hukum yang berakibat terhadap hilangnya hak-hak seseorang yang bersifat fisik maupun non fisik dan hilangnya harta benda untuk sementara waktu atau selamalamanya;

(2). ganti kerugian yang diberikan harus memperhitungkan: 1.hilangnya hak atas tanah, bangunan, tanaman, 2.hilangnya pendapatan dan sumber kehidupan lainnya, 3 bantuan untuk pindah ke lokasi lain dengan memberikan alternative lokasi baru yang dilengkapi dengan fasilitas yang layak, 4.bantuan pemulihan pendapatan agar dicapai keadaan setara dengan keadaan sebelum terjadinya pengambilalihan;

(3). mereka yang tergusur karena pengambilalihan tanah harus diperhitungkan dalam pemberian ganti kerugian harus diperluas.

(4). untuk memeperoleh data yang akurat tentang mereka yang terkena penggusuran dan besarnya ganti kerugian mutlak dilaksanakan survai dasar \& sosial ekonomi;

(5). perlu diterapkan instansi yang bertanggungjawab untuk pelaksanaan pengambilalihan dan pemukiman kembali;

(6). cara musyawarah untuk mencapai kesepakatan harus ditumbuhkembangkan

(7).perlu adanya sarana menampung keluhan dan dan menyelesaikan perselisihan yang timbul dalam proses pengambilalihan tanah. ${ }^{10}$

Sebagai suatu panduan agar maksud sebagaimana diutarakan Sumardjono di muka, maka dalam kontek sistem hukum dicantumkan azas/ prinsip agar bilamana di dalam sistem hukum terjadi sengketa, maka azas bertugas untuk menyelesaikan.

Berkenaan dengan kegiatan pengadaan tanah, maka menurut Boedi Harsono terdapat enam azas hukum pengadaan tanah yakni:

(1).Penguasaan dan penggunaan tanah oleh siapapun dan untuk keperluan apapun harus ada landasan haknya;

${ }^{10}$ Maria SW Sumardjono, "Kebijakan Pertanahan Antara Regulasi dan Implementasi", Edisi Revisi, (Jakarta: Buku Kompas, 2005), hal. 87-91. 
(2). Semua hak atas tanah secara langsung maupun tidak langsung bersumber pada hak bangsa;

(3). Cara memperoleh tanah yang sudah dihaki seseorang harus melalui kata sepakat antara para pihak yang bersangkutan;

(4).Dalam keadaan yang memaksa, jika jalan musyawarah tidak dapat menghasilkan kata sepakat, untuk kepentingan umum, penguasa dalam hal ini Presiden diberi kewenangan oleh hukum untuk mengambil tanah yang diperlukan secara paksa;

(5). Baik dalam acara perolehan atas dasar kata sepakat, maupun dalam acara pencabutan hak, kepada pihak yang telah menyerahkan tanahnya wajib diberikan imbalan yang layak;

(6). Rakyat yang diminta menyerahkan tanahnya untuk proyek pembangunan berhak untuk memperoleh pengayoman dari pejabat birokrasi. $^{11}$

Ditinjau dari dasar konstitusional Pasal $28 \mathrm{H}$ Ayat (4) Undang-undang Dasar 1945, maka perbuatan hukum pengadaan tanah baik yang dilakukan untuk kepentingan pemerintah atas nama negara dengan motif untuk kepentingan umum apalagi untuk kepentingan swasta harus menghormati hak perorangan sepenuhnya. Penghormatan hak perorangan atau individual merupakan sebuah keniscayaan yang wajib diberikan oleh negara khususnya kepada warga negara yang aset atau miliknya hanya sebidang tanah tersebut.

Hal inilah merupakan persoalan esensial sepanjang sejarah berdirinya negara Indonesia khususnya setelah diundangkannya Peraturan Menteri Dalam Negeri No.15 Tahun 1975 tentang Pembebasan Hak Atas Tanah tidak saja memiliki karakter hukum sebagai sebuah produk hukum yang cacat dan seharusnya batal demi hukum karena bertentangan dengan Undang-undang Dasar 1945 maupun Undang-undang No.5 Tahun 1960. Disamping itu merujuk pada pandangan Jimly Asshidiqie yang dinyatakannya:

Hal itu tercermin dalam pengertian negara hukum yang tercantum pada Pasal 1 Ayat (3) yang berbunyi negara Indonesia adalah Negara Hukum. Dalam paham negara hukumini diutamakan adalah hukum sebagai suatu kesatuan sistem bernegara. Sistem yang paling

\footnotetext{
${ }^{11}$ Oloan Sitorus dan Dayat Limbong, "Pengadaan Tanah Untuk Kepentingan Umum", Cetakan Pertama, (Yogyakarta: Mitra Kebijakan Tanah Indonesia, 2004), hal. 11 - 13.
} 
tinggi kekuasaannya bukanlah orang, tetapi sistem aturan yang dinamakan hukum. Hukumlah yang sesungguhnya berdaulat, bukan orang.Artinya dalam faham kedaulatan hukum ini, rakyat juga bukanlah pemegang kekuasaan tertinggi yang sebenarnya. Pemegang kekuasaan tertinggi dalam suatu negara adalah hukum, yang pengaturannya pada tingkat puncak atau tertinggi tercermin dalam konstitusi negara yaitu "the rule of constitution". Dalam kaitan itu di negara kita, hukum yang mempunyai kedudukan tertinggi adalah UUD Negara Republik Indonesia Tahun 1945, dimana tidak boleh ada hukum dan peraturan perundang-undangan yang bertentangan dengannya. ${ }^{12}$

Berkiblat pada pandangan Jimly sebagaimana diuraikan di muka, dikaitkan dengan produk hukum peraturan perundang-undangan mengenai pengadaan tanah sejak diberlakukan Peraturan Menteri Dalam Negeri No.15 Tahun 1975 sampai Keputusan Presiden No. 65 Tahun 2006 mengingkari hakikat negara hukum sebagaimana telah disepakati telah termaktub pada Undang-undang Dasar Negara Republik Indonesia Tahun 1945.

\section{Pembahasan Pasal per Pasal Krusial}

Dalam uraian penulis karena keterbatasan ruang penyajian yang tersedia sengaja mencantumkan beberapa pasal krusial yang akan menimbulkan masalah di kemudian hari, diperlukan pemikiran ulang serta sinkronisasi dan harmonisasi dengan peraturan perundang-undangan lain yang berkaitan.

\begin{tabular}{|c|c|c|c|}
\hline No. & Pasal & Bab/tentang & Keterangan \\
\hline 1. & $\begin{array}{l}\text { Pasal } 4 \text { huruf b pengadaan tanah } \\
\text { untuk kepentingan usaha swasta }\end{array}$ & $\begin{array}{l}\text { III/Pokok-pokok } \\
\text { Pengadaan Tanah } \\
\text { Bagian Kesatu } \\
\text { Umum }\end{array}$ & $\begin{array}{lr}\text { Bertentangan dengan } \\
\text { pengadaan tanah untuk } \\
\text { kepentingan } \\
\text { pembangunan bagi } \\
\text { kepentingan umum } \\
\text { harus memenuhi tiga } \\
\text { syarat: }\end{array}$ \\
\hline
\end{tabular}

12 Jimly Asshiddiqie, "Green Constitution, Nuansa Hijau Undang-undang Dasar Negara Republik Indonesia Tahun 1945", Cetakan Pertama, (Jakarta: Rajawali Pers, 2009), hal. 108. 


\begin{tabular}{|c|c|c|c|}
\hline & , & & $\begin{array}{l}\text { a. dilakukan oleh } \\
\text { pemerintah, b.dimiliki } \\
\text { oleh pemerintah dan } \\
\text { c.non profit/ nir-laba. } \\
\text { Sangat membahayakan } \\
\text { karena jika kepentingan } \\
\text { swasta yang jelas profit- } \\
\text { oriented berpotensi kuat } \\
\text { mengambil hak atas } \\
\text { tanah milik rakyat } \\
\text { khususnya yang level } \\
\text { bargainingnya sangat } \\
\text { rendah. }\end{array}$ \\
\hline 2. & Pasal 11 & $\begin{array}{lr}\text { III, Bagian } & \text { Ketiga } \\
\text { Pengadaan } & \text { Tanah } \\
\text { Untuk Kepentingan } \\
\text { Swasta }\end{array}$ & $\begin{array}{l}\text { Nampaknya RUU ini } \\
\text { terkooptasi oleh } \\
\text { kepentingan pemodal } \\
\text { khususnya skala besar } \\
\text { yang nyata berkarakter } \\
\text { profit oriented dengan } \\
\text { mengatasnamakan } \\
\text { kepentingan umum. } \\
\text { Mestinya pasal ini } \\
\text { dikeluarkan dari RUU } \\
\text { PTUP ini karena tidak } \\
\text { sesuai.Mekanisme } \\
\text { pengadaan tanah bagi } \\
\text { stratum ini seharusnya } \\
\text { melalui mekanisme } \\
\text { jual-beli biasa, berarti } \\
\text { nilai/ harga tanah } \\
\text { digantungkan pada } \\
\text { harga pasar. Namun } \\
\text { demikian subyek HAT } \\
\text { yang miskin hrs } \\
\text { didampingi agar tidak } \\
\text { mengalami } \\
\text { ketidakadilan dalam } \\
\text { proses musyawarah. } \\
\text { Alasan sebagai dasar } \\
\text { legitimasi kesesuai } \\
\text { dengan RTRW, RPJ- }\end{array}$ \\
\hline
\end{tabular}




\begin{tabular}{|c|c|c|c|}
\hline & & & $\begin{array}{lr}\text { Nas \& } & \text { Daerah } \\
\text { sesungguhnya } & \text { membuka } \\
\text { peluang } & \text { rekayasa } \\
\text { berkelanjutan } & \\
\end{array}$ \\
\hline 3. & Pasal 13 & $\begin{array}{l}\text { Pengadaan Tanah } \\
\text { Untuk Kepentingan } \\
\text { Umum }\end{array}$ & $\begin{array}{l}\text { Huruf a. berkait dengan } \\
\text { Pasal } 5 \text { Ayat (1) } \\
\text { khususnya pada huruf a } \\
\text { jalan tol, jaringan } \\
\text { telekomunikasi dan } \\
\text { informatika yang } \\
\text { dimiliki oleh investor } \\
\text { swasta bukan termasuk } \\
\text { kepentingan umum, } \\
\text { karena secara azasi } \\
\text { bertentangan dengan } \\
\text { azas PTUP karena jelas } \\
\text { profit-oriented }\end{array}$ \\
\hline 4. & Pasal 15 & $\begin{array}{l}\text { Pembangunan untuk } \\
\text { kepentingan umum } \\
\text { sebagaimana } \\
\text { dimaksud Pasal } 13 \\
\text { kecuali huruf } 1 \\
\text { dilakukan dengan } \\
\text { kerjasama: BUMN, } \\
\text { BUMD,BUMS }\end{array}$ & $\begin{array}{l}\text { Perbuatan hukum ini } \\
\text { akan mengakibatkan } \\
\text { policy pemerintah/ } \\
\text { pemda akan mendua/ } \\
\text { ambivalen apakah } \\
\text { mengutamakan } \\
\text { kepentingan rakyatnya } \\
\text { atau mengutamakan } \\
\text { kepentingan kegiatan } \\
\text { bisnis sendiri }\end{array}$ \\
\hline 5. & Pasal 51 & & $\begin{array}{lr}\text { Dalam hal terdapat } \\
\text { keberatan, gugatan atau } \\
\text { tuntutan } & \text { atas } \\
\text { pelaksanaan } & \text { PTUP, } \\
\text { instansi r yang } \\
\text { memerlukan tanah tetap } \\
\text { dapat melaksanakan } \\
\text { kegiatan pembangunan. } \\
\text { Rumusan ini jelas } \\
\text { menunjukkan adanya } \\
\text { pemaksaan sefihak, } \\
\text { menyimpangi prinsip } \\
\text { musyawarah bertenta- } \\
\text { ngan dengan sila }\end{array}$ \\
\hline
\end{tabular}




\begin{tabular}{|c|c|c|}
\hline & , & $\begin{array}{l}\text { keempat dan kelima } \\
\text { serta kedua. Seharus- } \\
\text { nya, sebelum disepa-kati } \\
\text { pihak yang memerlukan } \\
\text { tanah de-ngan alasan } \\
\text { apapun tidak dibenarkan } \\
\text { mela-kukan aktifitas } \\
\text { PTUP. Kewajiban pada } \\
\text { Pasal } 52 \text { mendaftarkan } \\
\text { tanah, justru akan } \\
\text { memicu sengketa } \\
\text { hukum antar pihak yang } \\
\text { blum ada } \\
\text { kesepakatan.Pendaftaran } \\
\text { tanah atas obyek tanah } \\
\text { yang belum ada } \\
\text { kesepakatan bertenta- } \\
\text { ngan dengan Pasal } 1320 \\
\text { KUH Perdata dan } \\
\text { merupakan perbuatan } \\
\text { melawan hukum yang } \\
\text { dilakukan oleh pengua- } \\
\text { sa/ pemerintah. }\end{array}$ \\
\hline 6. & Pasal 54 Ayat (1) & $\begin{array}{lr}\text { Pengadaan tanah untuk } \\
\text { kepentingan swasta } \\
\text { dapat dilaksanakan oleh } \\
\text { pihak swasta baik secara } \\
\text { perorangan maupun } \\
\text { badan hukum. } \\
\text { Perbuatan hukum } \\
\text { demikian sesungguhnya } \\
\text { bertentangan dengan } \\
\text { sila Pancasila, azas } \\
\text { PTUP serta nilai } \\
\text { keadilan sosial bangsa } \\
\text { Indonesiar Mengapa } \\
\text { demikian jelas bahwa } \\
\text { kepentingan perorangan, } \\
\text { kelompok pengusaha } \\
\text { lebih-lebih TNC/MNC/ } \\
\text { Konglomerasi/Kartel }\end{array}$ \\
\hline
\end{tabular}




\begin{tabular}{|c|c|c|c|}
\hline & & & $\begin{array}{l}\text { akan dengan mudah } \\
\text { melakukan } \\
\text { pengambilalihan tanah } \\
\text { rakyat miskin, } \\
\text { menimbulkan, } \\
\text { pemiskinan, penindasan, } \\
\text { memperlebar jurang } \\
\text { kemiskinan }\end{array}$ \\
\hline 7. & $\begin{array}{l}\text { Bab V Pasal } 54 \quad-60 \text { pengadaan } \\
\text { tanah untuk kepentinagn usaha } \\
\text { swasta }\end{array}$ & $\begin{array}{lr}\text { Tidak } & \text { dapat } \\
\text { dikualifi-kasikan } & \\
\text { sebagai } & \text { kegi-atan } \\
\text { atau rau perbuatan } \\
\text { hukum rang } \\
\text { termasuk } \\
\text { kepentingan pemba- } \\
\text { ngunan bagi kepenti- } \\
\text { ngan umum }\end{array}$ & 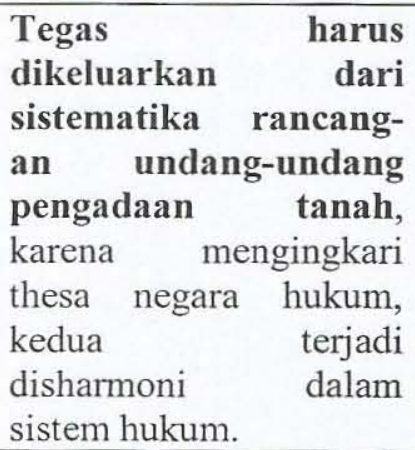 \\
\hline
\end{tabular}

\section{Simpulan}

Sebagai suatu simpulan dari uraian telaah sebagaimana diuraikan pada bagian terdahulu, maka dapat dirumuskan sebagai berikut:

(1). Kelemahan substansial pada materi rancangan undang-undang pengadaan tanah untuk kepentingan umum belum tertangani, alih-alih justru kepentingan profit justru bersembunyi tegasnya berlindung di balik kepentingan umum. Dengan demikian nyata sudah diperlukan adanya sikap kritik dan penolakan atas kehadiran rancangan undang-undang yang bakal menciptakan ketidakadilan dan resistensi ini.

(2). Inkonsistensi rancangan undang-undang pengadaan tanah sesungguhnya merupakan langkah mundur pengaturan karena kembali pada pengaturan pengambilalihan tanah menurut Peraturan Menteri dalam Negeri pada era Orde Baru. Disamping itu, diprediksi implikasi hukum dari pengundangan rancangan undang-undang akan semakin menumbuhkembangkan kasus agraria. 


\section{Rekomendasi}

Rekomendasi penulis, rancangan undang-undang ini harus ditolak karena cacat hukum. 


\section{Daftar Pustaka}

Asshiddiqie, Jimly. Green Constitution, Nuansa Hijau Undang-undang Dasar Negara Republik Indonesia Tahun 1945, Cetakan Pertama, Jakarta: Rajawali Pers, 2009.

Koeswahyono, Imam. Melacak Dasar Konstitusional Pengadaan Tanah Untuk Kepentingan Pembangunan Bagi Umum, dalam Jurnal Konstitusi PPKFH Universitas Brawijaya dan Mahkamah Konstitusi Republik Indonesia, Vol I No.1 Agustus 2008.

Mertokusumo, Sudikno. Penemuan Hukum, Sebuah Pengantar, Cetakan Pertama, Yogyakarta: Liberty, 1996. Atmajaya, 2011.

. Teori Hukum, Cetakan Pertama, Yogyakarta: Universitas

Notonagoro. Beberapa Hal Mengenai Falsafah Pancasila,Pidato Dies Natalis

Ke I Universitas Pantjasila, Djakarta, Cetakan Kedelapan, Djakarta: Pantjuran Tudjuh, 1979.

Sihombing, Ulli Parulian, dkk (Perumus). Mengajarkan Hukum Yang Berkeadilan, Cetak Biru Pembaruan Pendidikan Hukum Berbasis Keadilan Sosial, Cetakan Pertama, Jakarta: ILRC \& OSI, 2009.

Sitorus, Oloan, dan Dayat Limbong. Pengadaan Tanah Untuk Kepentingan Umum, Cetakan Pertama, Yogyakarta: Mitra Kebijakan Tanah Indonesia, 2004.

Sumardjono, Maria SW. Kebijakan Pertanahan Antara Regulasi dan Implementasi, Edisi Revisi, Jakarta: Buku Kompas, 2005.

\section{Media Massa/Situs Internet/Bahan Hukum}

Idham Arsyad, "Sesat Pikir RUU Pengadaan Tanah", KOMPAS, Jum'at 18 Maret 2011: 6

“Ancaman Hak Atas Tanah”, KOMPAS, Jum'at 11 Maret 2011: 4

Rancangan Undang-undang tentang Pengadaan Tanah Untuk Pembangunan dengan Surat Pengantar Presiden Republik Indonesia tanggal 15 Desember 2010 No.R-98/Pres/12/2010. 